\title{
PERANCANGAN BUKU CERITA BERGAMBAR TENTANG PERAN MIKROBIOTA PADA TUBUH MANUSIA
}

\author{
Dimas Agung Pangestu ${ }^{1)}$, Daffa Satria Alvareza ${ }^{2)}$, Imawan Majid ${ }^{3)}$ \\ Program Studi Desain Komunikasi Visual \\ Fakultas Bahasa dan Seni Universitas Indraprasta PGRI \\ Jl. Nangka 58 Tanjung Barat, Jakarta Selatan, 12530 \\ diamsagung@gmail.com
}

\begin{abstract}
Abstrak
Perancangan buku cerita bergambar ini menghasilkan sebuah buku cerita bergambar yang terdiri dari cover dan isi buku. Menggunakan konsep desain dan analisis segmentasi yang tepat dengan pemilihan target yang sesuai. Target utama dari perancangan buku cerita bergambar ini adalah untuk anak-anak usia sepuluh sampai lima belas tahun. Konsep desain dan strategi kreatif yang diterapkan adalah menggunakan gaya ilustrasi flat design, gambar dibuat dengan warna yang cerah dan smooth, serta teks isi dan judul menggunakan font serif serta huruf galang dan knickback, yang fleksibel dan tidak kaku untuk anak-anak sehingga mudah dibaca. Gaya visual dari pembawaan teks buku cerita bergambar yang dipakai bersifat berdongeng atau naratif. Tujuan buku cerita bergambar ini memberikan isi pesan yang bersifat mengajak, mengedukasi dan memberikan informasi melalui buku cerita bergambar. Perancangan buku cerita bergambar ini kami harap dapat meningkatkan ilmu pengetahuan mengenai mikrobiologi serta meningkatkan minat untuk membaca buku terutama untuk anak, salah satunya adalah peran mikrobiota pada tubuh.
\end{abstract}

Kata kunci: Buku cerita, Mikrobiota, Edukatif

\begin{abstract}
The design of the illustrated Storybook produced a picture book consisting of covers and content of books. Use the right design concept and segmentation analysis with appropriate target selection. The main Target of the design of the Illustrated storybook is for children aged ten to fifteen years. The concept of design and creative strategy applied is to use a flat design illustration style, the image is made with bright and smooth colors, as well as the contents text and title using serif fonts as well as the letters and knickbacks, which are flexible and not rigid for children so easy to read. The visual style of the text-Book of the Illustrated Storybooks is storytelling or narrative. The purpose of this illustrated storybook gives the message of inviting, educating and providing information through a picture book. The design of this illustrated storybook we hope to improve the science of microbiology and increase interest in reading books especially for children, one of which is the role of microbiota on the body.
\end{abstract}

Keyword: Storybook, Microbiota, Education

Correspondence author: Dimas Agung Pangestu, diamsagung@gmail.com, Jakarta, and Indonesia

This work is licensed under a CC-BY-NC 


\section{PENDAHULUAN}

Mikrobiologi adalah cabang biologi yang mempelajari mikroorganisme (Hasmiati., 2016). Mikrobiologi merupakan cabang ilmu biologi yang menarik untuk dipelajari bagi anakanak, terutama anak yang suka dengan hal yang bertema tentang kehidupan dan sains. Salah satu cabang ilmu mikrobiologi membahas tentang mikroorganisme yang tidak bisa dilihat secara kasat mata seperti mikroorganisme. Mikroorganisme adalah makhluk hidup yang sangat kecil yang diklasifikasikan dalam kelas protista yang terdiri dari bakteri, jamur, protozoa dan ganggang (Sudarmono, 2016). Mikroorganisme memiliki jenis dan spesies yang hidup di sekitar kita dengan jumlah yang sangat banyak, namun tidak terlihat oleh mata kita karena terlalu kecil. Selain hidup di sekitar kita, mikroorganisme ini tumbuh dan hidup di tubuh manusia dan tentunya dengan jumlah yang sangat banyak. Beberapa mikroorganisme bersifat menguntungkan dan ada pula yang merugikan, baik terhadap manusia ataupun hewan. Oleh karena itu untuk mengetahui segala sesuatu tentang mikroorganisme perlu adanya cabang ilmu mikrobiologi (ChunFeng, 2018).

Jumlah mikroorganisme, secara kolektif dikenal sebagai mikrobiota. Mikrobiota dapat dianggap sebagai komunitas mikroorganisme (bakteri, virus, arkae dan beberapa uniseluler) yang hidup dalam suatu lingkungan spesifik (ChunFeng, 2018). Menjadikan mikrobiota berupa kumpulan dari komunitas mikroorganisme yang bersimbiosis mutualisme dengan manusia dan hidup di dalam tubuh manusia. Para mikrobiota ini berperan penting dalam kelangsungan kehidupan suatu makluk hidup terutama pada manusia. Mikrobiota ini tidak semuanya jahat dan membahayakan tubuh manusia. Sebagaimana dilansir dari Mother Nature Network, mikrobamikroba yang ada pada manusia memiliki pengaruh besar pada sistem kinerja tubuh. Mikroba bukan hanya bakteri atau virus pembawa penyakit yang membahayakan bagi tubuh kita, ada juga bakteri atau virus yang bermanfaat bagi tubuh.

Namun, pengetahuan pengenalan pengetahuan untuk anak masih terbatas dan juga rendahnya minat membaca buku di indonesia. Berdasarkan studi Most Littered Nation in the World yang dilakukan oleh Central Connection State University pada Maret 2016 lalu, Indonesia dinyatakan menduduki peringkat ke-60 dari 61 negara soal minat membaca. Indonesia persis berada di bawah Thailand di atas Bostwana (Halim \& Munthe, 2019). Padahal dengan membaca banyak pengetahuan yang bisa didapatkan, belum adanya kebiasaan yang membentuk karakter untuk pembentukan minat dan motivasi untuk belajar. Jika minat dan motivasi tidak ada, pada umumnya kebiasaan tidak tumbuh dan tidak berkembang (Rahma, 2015). Maka dari itu Kebiasaan membaca memang harus diterapkan sejak dini, yaitu dengan memberikan buku bacaan pada anak dan mendidik anak untuk membaca buku.

Media pembelajaran adalah sarana komunikasi dalam proses belajar mengajar yang berupa perangkat keras maupun perangkat lunak untuk mencapai proses dan hasil intruksional secara efektif dan efisien, dan supaya tujuan intruksional tercapai dengan mudah (Rahma, 2015). Media merupakan medium yang digunakan untuk membawa penyampai sesuatu pesan, di mana medium itu merupakan jalan atau alat dengan suatu pesan berjalan dengan komentator dengan komunikam, media juga merupakan segala benda yang manipulasikan. Untuk memberikan ilmu serta edukasi kepada anak tentang pengetahuan mikrobiologi dibutuhkan sebuah media, salah satunya adalah buku cerita bergambar.

Buku cerita bergambar atau cergam dapat menjadi suatu media dalam menyampaikan pesan melalui cerita dengan disertai ilustrasi gambar. Buku itu sendiri merupakan suatu media dalam menyampaikan informasi dan pesan (Rahma, 2015). Buku cerita bergambar dipilih sebagai media pembelajaran karena anak-anak tertarik untuk belajar dan lebih cepat mengerti jika diberi visualisasi yang menarik dan memiliki banyak warna, karena anak-anak menyukai sesuatu yang kreatif. dengan desain yang menarik dan kreatif agar anak dapat belajar hal baru. Dengan membaca buku cerita bergambar ini dapat meningkatkan imajinasi anak, membuat mereka aktif berpikir kreatif, meningkatkan rasa ingin tahu, dan juga memperluas ilmu pengetahuan dan kosa kata mereka (Emosda, 2017).

Buku ini juga diharapkan dapat melatih kemauan anak dalam membaca. Ilustrasi serta alur menyampaikan materi yang ada pada buku cerita ini, nantinya akan dibuat semenarik mungkin dengan alur cerita yang memiliki unsur fantasi yang menyenangkan. Para orang tua pun 
nantinya bisa menggunakan buku ini untuk mendampingi anaknya dalam belajar, sehingga mampu memupuk kedekatan antara anak dan orang tua. Selain itu para orang tua juga bisa menggunakan buku cerita bergambar ini sebagai media pembelajaran alternatif. Rumusan masalah dalam penelitian ini adalah bagaimana pembahan materi tentang mikroorganisme dapat di implementasikan ke dalam media. Kemudian, bagaimana merancang, mengembangkan, mengimplementasikan serta mengevaluasi kebermanfaatan dari buku cerita bergambar untuk anak.

\section{METODE PENELITIAN}

Peneliti melakukan penelitian dengan menggunakan metode kualitatif. Menurut Bogdan dan Taylor (1975) yang dikutip oleh Moleong (2007: 4) mengemukakan bahwa metodologi kualitatif sebagai prosedur penelitian yang menghasilkan data deskriptif berupa kata-kata tertulis atau lisan dari orang-orang atau perilaku yang dapat diamati. Dengan metode kualitatif ini bisa mendapatkan informasi langsung tentang ilmu mikrobiologi dan data yang dibutuhkan. Untuk memperoleh data, peneliti menggunakan beberapa metode yang disesuaikan pada jenis penelitian kualitatif dengan cara, antara lain:

\section{Pengumpulan Data Premier}

Observasi adalah metode pengumpulan data secara sistematis melalui pengamatan dan pencatatan terhadap fenomena yang diteliti (Pratiwi, 2009: 63). Proses mengumpulkan data dengan cara observasi langsung di lapangan yaitu melihat buku-buku pembelajaran dan buku cerita bergambar mengenai mikroorganisme yang ada di toko buku Gramedia. Hasil pengamatan dari observasi tersebut untuk pengumpulan data dan informasi mengenai mikroorganisme dan buku cerita bergambar.

\section{Pengumpulan Data Sekunder}

Selain itu, untuk mendapatkan data berupa dokumen tentang mikroorganisme dan peran mikrobiota pada tubuh menggunakan metode pengumpulan data sekunder, data sekunder adalah data yang diperoleh dalam bentuk yang tersedia melalui publikasi dan informasi yang dikeluarkan di berbagai organisasi atau perusahaan termasuk jurnal (Koentjaraningrat, 1977). Studi pustaka dilakukan dengan mengumpulkan bahan literatur tertulis yang berhubungan dengan objek kajian antara lain berupa buku, dan beberapa jurnal ilmiah. Berikut pengumpulan data sekunder yang kami lakukan untuk memperoleh data mengenai mikroorganisme.

\section{Kepustakaan}

Studi kepustakaan ini digunakan dalam proses penelitian sejak awal hingga akhir penelitian dengan cara memanfaatkan berbagai macam pustaka yang relevan dengan fenomena sosial yang tengah dicermati (Pratiwi, 2009: 63). Dalam hal ini kami akan menggunakan buku atau literatur sebagai informasi serta landasan yang berkaitan dengan objek yang akan diangkat sebagai referensi daftar pustaka.

\section{Kajian Internet}

Pencarian data secara online ialah pencarian dengan menggunakan komputer yang dilakukan melalui internet yang tersebar di berbagai penjuru dunia (Sarwono, 2007: 105). Dengan adanya internet dapat memudahkan mencari data-data dari situs-situs resmi dan relevan yang memiliki data-data yang berkaitan dengan objek pembahasan.

\section{HASIL DAN PEMBAHASAN}

\section{Awal Perkembangan Mikroorganisme di Tubuh Manusia}

Kolonisasi mikroba terjadi karena telah terpajannya janin dengan plasenta dan meconium (ChunFeng, 2018). Pada keadaan alamiah, janin manusia tidak memiliki mikroorganisme, janin manusia baru akan memperoleh mikroorganisme ketika melewati sepanjang saluran lahir. 
Terdapat berbagai mikrobiota seperti Firnicutes, Tenericutes, Proteobacteria, Bacteroidetes, dan Fusobacteriaphyla. Diperolehnya mikrobiota melalui kontak permukaan, penelanan atau penghisapan di dalam saluran lahir. Mikroba-mikroba ini segera disertai oleh mikroba-mikroba lain dari banyak sumber yang langsung berada di sekeliling bayi yang baru lahir tersebut sehingga menciptakan komunitas mikroba.

Collado et al. (2006) menyatakan bahwa pencegahan NCDs (penyakit tidak menular) dapat dilakukan dengan memperhatikan mikrobioma sejak awal kehidupan. Sistem gastrointestinal bayi akan memberikan lingkungan baru bagi kolonisasi mikroba. Mikrobiota bayi yang dilahirkan dengan persalinan normal memiliki kemiripan dengan mikrobiota di vagina ibunya pada 20 menit awal kehidupan. Menyebabkan faktor mikrobiota bayi akan mengikuti mikrobiota ibunya karena proses kelahiran.

Bakteri pada mikrobiota manusia memiliki peran pada imunitas, nutrisi, dan perkembangan manusia. Bakteri yang hidup di dalam tubuh manusia merupakan koloni bakteri yang bermanfaat. Peran mikrobioma adalah membantu mencerna makanan, mengatur sistem imun, dan perlindungan terhadap bakteri Pathogen. Mikrobioma berada di kulit, sistem gastrointestinal, saluran napas, dan saluran urogenital; saluran yang berhubungan langsung dengan dunia luar sehingga dapat terpajan langsung oleh faktor eksternal, seperti makanan, udara, dan obatobatan. Setiap individu memiliki respons berbeda pada metabolisme mikrobioma. Bahkan bakteri baik tersebut harus dianggap sebagai bagian dari genom. Mikrobiota baik yang berada pada flora manusia normal memiliki peran penting untuk menjaga ekosistem tubuh.

\section{Peran Mikrobiota pada Sistem Pencernaan}

Jumlah mikrobioma pada manusia paling banyak terdapat di usus (Sudarmono, 2016). Mikrobiota tersebar di beberapa bagian tubuh manusia, namun mikrobiota paling banyak berada pada saluran pencernaan. Data dari MDB (Microbiome Database) $70 \%$ mikrobiota pada manusia sebagian besar hidup di dalam usus, di mana ditemukan 100 triliun sel-sel mikrobiota yang terdiri dari 1.000 spesies yang berbeda. Kolon dan usus besar merupakan tempat yang paling banyak dihuni oleh mikroorganisme (ChunFeng, 2018). Selain pada bagian pencernaan, mikrobiota juga berada di beberapa bagian tubuh yang mendeteksi adanya aktivitas mikrobiota. Menurut data dari HOMD (Human Oral Microbiome Database) mikrobiota manusia terdiri dari 100 juta sel bakteri dan 700 spesies yang teridentifikasi di dalam mulut manusia.

Peran mikrobiota dalam menjaga keseimbangan jumlah mikroba merupakan faktor yang mempengaruhi kesehatan tubuh manusia. Mikrobiota menjaga agar bakteri jahat (patogen) tidak berkembang terlalu banyak pada saluran pencernaan, ada beberapa faktor yang berperan untuk sistem pencernaan. Faktor saluran cerna dapat berupa struktur mukosa, digestif dan absorbsi, sistem imun, sistem saraf enterik, dan motilitas, sistem barrier mukosa. Faktor-faktor ini merupakan faktor yang berperan dalam kesehatan saluran cerna (Bischoff, 2011; Bischoff et al., 2014). Tanpa mikrobiota usus, tubuh manusia tidak akan mampu memanfaatkan beberapa karbohidrat yang belum tercerna untuk mengkonsumsi, karena beberapa jenis mikrobiota usus memiliki enzim di mana sel-sel manusia tidak mampu untuk memecahkannya khususnya polisakarida. Manusia membutuhkan sumber energi dan nutrisi yang cukup, mikrobiota pada usus dapat mengubah karbohidrat dengan berfermentasi menjadi asam lemak rantai pendek atau disebut dengan fermentasi sakarotonik. Produk ini dapat digunakan oleh sel inang, menyediakan sumber utama energi dan nutrisi bagi manusia, serta membantu tubuh menyerap mineral penting seperti kalsium, magnesium, dan zat besi. Gas dan asam organik (seperti asam laktat) juga diproduksi oleh fermentasi sakarolitik.

Sistem gastrointestinal manusia (sistem pencernaan) adalah rumah dari sebagian besar mikroba, peran mikrobiota pada saluran usus untuk menjaga tubuh dan keseimbangan komposisi yang disebut dengan eubiosis (status seimbang antar populasi bakteri di dalam saluran gastrointestinal). Keadaan ketidakseimbangan populasi mikrobiota dalam saluran cerna disebut sebagai dysbiosis, disfungsi mikroflora gastrointestinal tersebut dapat menyebabkan munculnya berbagai gangguan kesehatan (Suryawan, 2018). Ketika terjadinya dysbiosis pada sistem pencernaan akibat mikrobiota jahat lebih dominan daripada mikroba baik adanya disfungsi sistem 
imun dan kesalahan regulasi inflamasi, menyebabkan gangguan kesehatan berupa turun nya sistem imun dan kekebalan tubuh. Selain itu, gangguan pada mikrobioma dapat meningkatkan risiko infeksi (ChunFeng, 2018). Hal ini yang menyebabkan kenapa harus tetap memperhatikan menjaga keseimbangan pertumbuhan mikrobiota pada sistem pencernaan berperan penting dalam sistem pencernaan, untuk mencegah terjadinya penyebab non-communicable disease and conditions yaitu penyakit yang tidak menular (Susmiati, 2019).

Menurut Bischoff, ada 5 kriteria utama menandakan sistem pencernaan yang sehat

1. Tanda-tanda spesifik saluran cerna sehat

a. Pencernaan dan penyerapan makanan yang efektif.

b. Status saluran cerna normal dan penyerapan efektif makanan, air dan mineral.

c. Buang air besar teratur, waktu transit normal dan tidak ada rasa sakit perut.

d. Konsistensi tinja normal dan jarang mual, muntah, diare, sembelit dan kembung.

2. Tidak adanya penyakit saluran cerna

a. Tidak ada penyakit asam lambung, penyakit gastroesophageal reflux atau penyakit radang lambung lainnya.

b. Tidak ada kekurangan enzim atau intoleransi karbohidrat.

3. Mikrobiota usus yang normal dan stabil

a. Tidak ada pertumbuhan bakteri yang berlebihan.

b. Komposisi normal dan vitalitas microbiome usus.

c. Tidak ada infeksi saluran cerna atau diare terkait antibiotik.

4. Status kekebalan yang efektif

a. Fungsi saluran cerna penghalang yang efektif, produksi lendir yang normal dan tidak ada peningkatan translokasi bakteri.

b. Kadar IgA normal, angka yang normal dan aktivitas normal sel-sel kekebalan tubuh.

c. Toleransi kekebalan dan tidak ada alergi atau hipersensitivitas mukosa.

5. Status kesejahteraan

a. Kualitas hidup normal Life Qi (chi), atau perasaan yang nyaman pada usus.

b. Produksi serotonin seimbang dan fungsi normal dari sistem saraf enterik.

\section{Peran Mikrobiota pada Sistem Imun Tubuh}

Pengaruh dari mikrobiota usus terhadap kesehatan manusia adalah berkelanjutan dari lahir hingga dewasa. Faktor lingkungan, faktor nutrisi, dan faktor telah dilibatkan dalam perkembangan untuk simbiosis dari kesehatan usus dan mikrobiota (Kurniati, 2016). Mikrobiota dalam Usus mempengaruhi imunitas dan kekebalan tubuh, ketika tubuh mengalami ketidakseimbangan komposisi mikrobiota pada usus atau yang disebut dengan dysimbiosis, maka akan berpengaruh ke bagian sistem imun tubuh. Hal ini membuktikan bahwa ada interaksi antara mikrobiota usus dan sistem kekebalan tubuh. Interaksi ini mungkin terkait dengan menjaga keseimbangan antara mikrobiota usus dan sistem sumbu kekebalan tubuh (emadwiandr, 2013).

Hubungan antara sel-sel sekresi-IgA dan komposisi mikrobiota. Antibodi A (Immunoglobulin A, IgA) adalah antibodi yang memainkan peran penting dalam mukosa, memberikan perlindungan permukaan organ tubuh yang terpapar dengan mencegah penempelan bakteri dan virus. Dalam penelitian ini, menafsirkan pentingnya hubungan usus buntu dengan jaringan limfoid di IgA. Penelitian ini menemukan penurunan sel IgA pada usus besar yang diserang oleh bakteri jahat, serta penurunan tingkat IgA di feses, karena koloni bakteri. Namun, normalisasi pada sel sekresi-IgA di kolon berkorelasi dengan peningkatan dan pembesaran jaringan limfoid usus. Dengan demikian, hasil ini menunjukkan bahwa sel-sel sekresi-IgA terlibat dalam pemeliharaan mikroba dalam usus besar dan berkontribusi untuk membentuk koloni mikroba normal.

\section{Mikrobiota Baik Probiotik}

Probiotik didefinisikan sebagai mikrobia hidup yang memiliki kemampuan terapeutik pada manusia yang mengkonsumsi makanan atau minuman yang mengandung bakteri probiotik (Studi et al., 2011). Probiotik merupakan salah satu mikrobiota baik yang berada di dalam tubuh 
manusia terutama pada usus, termasuk dalam friendly colonizer yang bisa di dapatkan di dalam makanan atau minuman yang mengandung probiotik, probiotik berperan penting dalam menghambat pertumbuhan bakteri jahat (patogen). Cara kerja dari probiotik ini dengan memperbaiki keseimbangan mikrobia yang sudah terdapat dalam saluran pencernaan manusia (Fuller,1989). Komposisi mikrobiota baik lebih banyak daripada mikrobiota jahat dengan perbandingan $80 \%$ mikrobiota baik dan 20\% mikroba jahat (Studi et al., 2011).

\section{Peranan Buku Cerita Bergambar}

Peranan buku cerita bergambar sangat penting, karena dapat membantu siswa belajar tentang alam, mengenal orang lain dan hubungan yang terjadi dan pengembangan perasaan. Dengan demikian, anak dapat memahami dan menghubungkannya dengan pengalaman pribadinya, menstimulasi imajinasi, memperoleh kesenangan serta keberadaan di tengah masyarakat (Rahma, 2015).

Dengan karakteristik anak usia dini yang berada pada tahap pra operasional konkret, maka anak masih membutuhkan benda-benda konkrit untuk membantu proses berpikir. Anak usia dini juga masih sedang mengembangkan keterampilan berpikir dan bahasanya. Dengan demikian, penggunaan buku cerita bergambar merupakan satu cara yang baik dan tepat untuk menyampaikan materi pengetahuan atau pembelajaran agar perkembangan anal lebih optimal.

\section{Hasil Pengumpulan Data Premier}

Untuk mendapatkan data primer dilakukan observasi dengan mengunjungi beberapa toko buku dan perpustakaan sekolah. Dari observasi tersebut ditemukan fakta bahwa perpustakaan sekolah memiliki koleksi buku-buku pelajaran tentang mikroorganisme, namun sebagaian besar cenderung berisi lebih banyak tulisan dan sedikit penjelasan visual. Hal itu membuat anak-anak menjadi kurang tertarik untuk membacanya. Bahasa yang disampaikan pada buku tersebut juga terbilang berat atau sulit dimengerti oleh anak-anak, sehingga anak-anak sulit untuk menyerap materi yang ada di buku tersebut.

\section{Hasil Pengumpulan Data Sekunder}

Untuk mendapatkan data berupa dokumen tentang mikroorganisme dan peran mikrobiota pada tubuh, digunakan metode pengumpulan data sekunder. Metode ini dipilih untuk memperoleh data, informasi, mengolah dan menganalisis sekaligus untuk penyusunan penelitian pustaka, literatur, dan artikel yang berada di internet.

Buku cerita bergambar memiliki dampak yang baik untuk anak usia dini. Dalam sebuah penelitian ditemukan bahwa pengetahuan tentang lingkungan dapat ditingkatkan dalam diri anakanak lewat buku cerita bergambar, terutama karena berdampak pada kehidupan sehari-hari mereka. Retnowati, dkk (2018:89-95) melakukan penelitian dengan tujuan untuk mengetahui efektivitas gambar dalam membaca buku cerita untuk meningkatkan kebaikan pada anak. Hasilnya disimpulkan bahwa ada perbedaan yang signifikan dari nilai rata-rata tes dan pengukuran posttes kebaikan. Itu artinya membaca buku bergambar secara efektif dapat meningkatkan kebaikan anak-anak berusia 5-6 tahun (Halim \& Munthe, 2019).

Penilaian tinggi rendahnya minat baca dapat diketahui melalui aspek Kesadaran akan manfaat membaca (Wulandari, 2017). Perhatian terhadap membaca buku, Rasa senang terhadap membaca buku, dan Frekuensi membaca buku. Maka dari itu untuk meningkatkan rasa senang anak untuk membaca buku perlunya memanfaatan media belajar melalui buku cerita bergambar. Materi yang cukup kompleks akan di sederhanakan agar materi menjadi ringan dan dipahami anak. Kehadiran buku cerita bergambar menjadi sesuatu yang umum dan sangat disukai oleh anak-anak. Dipakai juga sebagai salah satu sumber pembelajaran. Menarik sebagai sumber pembelajaran, karena cerita dapat divisualisasikan dengan gambar dan warna-warna yang menarik sesuai dengan alur dan latar cerita. 


\section{Konsep Dasar Perancangan Buku Cerita Bergambar}

Konsep perancangan dari buku cerita bergambar diperlukan untuk mengetahui bagaimana untuk membuat buku cerita bergambar yang kreatif dan sesuai dengan target (Mahardika et al., 2020). Dibutuhkannya beberapa komponen dari mulai analisis target pasar, strategi, serta konsep visual untuk membuat rancangan buku cerita bergambar.

\section{Analisis Target Segmentasi Pasar}

Untuk menentukan target pasar, haruslah menentukan analisis target segmentasi pasar terlebih dahulu (Mahardika et al., 2020). Analisis utama untuk menentukan segmentasi pasar yaitu Demografi, Geografis, Psikografis. Adapaun target segmentasi pasar dari buku cerita edukasi bergambar ini dapat diuraikan sebagai berikut:

\section{Demografis}

Segmentasi demografis adalah membagi target pasar menjadi sejumlah kelompok berdasarkan usia, jenis kelamin, penghasilan, pekerjaan, pendidikan, kebangsaan dan kelas sosial (Kotler, 2004: 291). Berdasarkan faktor demografisnya, perancangan buku cerita bergambar tentang mikroorganisme dan peran mikrobiota ditujukan untuk:

1. Target Primer

Anak-anak rentang usia 10 sampai 15 tahun. Anak-anak dipilih sebagai target primer karena buku cerita bergambar ini berisikan edukasi tentang ilmu pengetahuan yang dapat memberikan pembelajaran kepada anak-anak tentang mikroorganisme dan peran mikrobiota pada tubuh.

2. Target Sekunder

Orang tua dengan rentan usia 25 sampai 35 tahun yang memiliki kepedulian terhadap pendidikan anak. Orang tua mendamping anak untuk sama-sama belajar mengenai mikrobiologi.

\section{Geografis}

Segmentasi geografis adalah membagi target pasar menjadi unit-unit geografis yang berbeda-beda seperti daerah kabupaten, kota atau pemukiman (Kotler, 2004: 289). Berdasarkan faktor geografisnya, kami menargetkan kota-kota besar sebagai lokasi pemasaran, khususnya di kota Jakarta dan Bogor.

Hal ini karena buku-buku yang beredar di Jakarta dan Bogor masih jarang untuk jenis buku cerita bergambar yang membuat infomasi dan pengetahuan tentang mikroorganisme, dan juga materi mengenai mikrobiologi bahasanya cukup berat dan kompleks untuk anak-anak. Wilayah perkotaan juga memiliki banyak tempat untuk memasarkan buku khusus nya untuk anak.

\section{Psikografis}

Segmentasi psikografis adalah membagi target pasar menjadi kelompok-kelompok yang berbeda berdasarkan gaya hidup dan karakteristik kepribadian (Kotler, 2004: 294). Dalam hal ini, dilihat dari psikografisnya target yang kami pilih adalah sebagai berikut:

1. Target Primer

Anak-anak yang gemar membaca dan menyukai hal-hal yang unik serta penuh imajinasi. Selain itu kami menargetkan kepada anak-anak yang sulit untuk memahami bahasa yang komples dan teks yang bersifat narasi, sehingga tidak rumit dan komspleks untuk anak-anak dengan cara edukasi yang menyenangkan dan gambar yang mudah dipahami.

2. Target Sekunder

Orang tua yang menyukai hal-hal yang lucu dan ceria untuk anak mereka, dengan begitu orang tua akan memberikan anak mereka dengan ilustrasi yang menurut mereka lucu dan ceria untuk anak-anak. Sehingga orang tua dapat membacakan buku tersebut secara bersamasama bersama anak, orang tua dapat membimbing anak mereka untuk belajar bersama. 


\section{Strategi Kreatif}

Strategi kreatif adalah kebijakan yang akan dilakukan terhadap panduan kreatif, terdiri dari isi pesan dan bentuk pesan, yang disusun berdasarkan target audience, karena pada dasarnya target audience lah yang menentukan isi (content) dan bentuk (form) pesan iklan yang akan disampaikan (Sanyoto, 2006: 83). Adapun strategi kreatif yang gunakan yaitu:

1. Pesan

Pesan yang bersifat edukatif dan informatif akan diterapkan pada buku dan bentuk pesan yang ingin disampaikan dalam perancangan buku cerita bergambar ini adalah pesan yang bersifat mengajak (persuasif), mengedukasi (edukatif) dan memberikan informasi (informatif). Serta gaya bahasa yang digunakan adalah gaya bahasa yang non formal namun tetap sopan, teks yang naratif yang seperti berdongenng mampu menarik perhatian anak-anak. Serta para orang tua bisa bercerita kepada anak nya melalui buku cerita bergambar ini.

2. Strategi Visual

Strategi visual yang digunakan pada buku cerita bergambar ini menggunakan warna-warna cerah dan smooth yang akan membuat kesan menyenangkan dan ceria untuk para anak-anak, dengan latar yang terang serta menampilkan karakter tokoh anak kecil bertugas sebagai pemandu yang mampu menjelaskan apa yang terjadi pada pada buku cerita bergambar ini.

3. Gaya Visual

Strategi visual yang digunakan pada buku cerita bergambar ini menggunakan flat design yang simple dengan dominan warna-warna cerah dan smooth yang akan membuat kesan menyenangkan dan ceria, serta menampilkan karakter tokoh anak kecil yang naratif sebagai pemandu pada buku cerita bergambar ini.

4. Positioning

Dengan pertimbangan bahwa buku tentang mikroorganisme ini cukup kompleks dan sulit dipahami oleh anak-anak, peneliti menempatkan buku cerita bergambar ini dengan bahasa yang ringan dan tidak berat untuk dibaca. Buku cerita bergambar menjadi solusi untuk membuat materi yang rumit menjadi bahasa yang mudah dipahami oleh anak-anak, dilihat dari isi yang bersifat naratif dan informatif dengan bahasa yang ringan seperti berdongeng sehingga mudah dipahami oleh anak-anak.

\section{Hasil Visualisasi Desain}

Setelah merancang sebuah konsep yang akan dijadikan buku cerita bergambar, maka hasil dari pengerjaan pembuatan buku cerita bergambar terdiri dari cover dan isi bisa menjadi bacaan buku yang menarik, kreatif dan edukatif sebagai solusi agar anak dapat belajar tentang mikroorganisme. Berikut hasil dari pembuatan buku cerita bergambar mikroorganisme:

\section{Cover Buku Cerita Bergambar}

Pada cover buku cerita bergambar kami menampilkan latar yang berada di dalam tubuh manusia dengan sel-sel yang di transparasi, kami menggunakan warna dominan biru terang dan merah jambu, menampilkan beberapa ilustrasi mikroorganisme sebagai identitas buku mikroorganisme. 


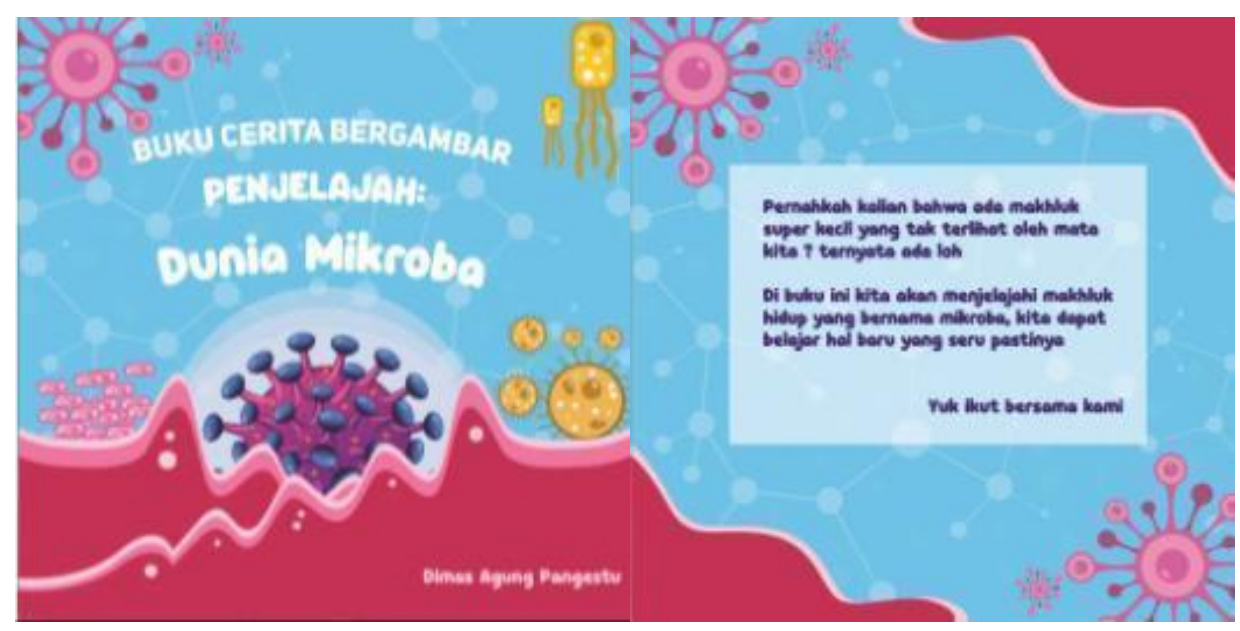

Gambar 1. Contoh cover dari buku cerita bergambar mikroorganisme

\section{Isi Buku Cerita Bergambar}

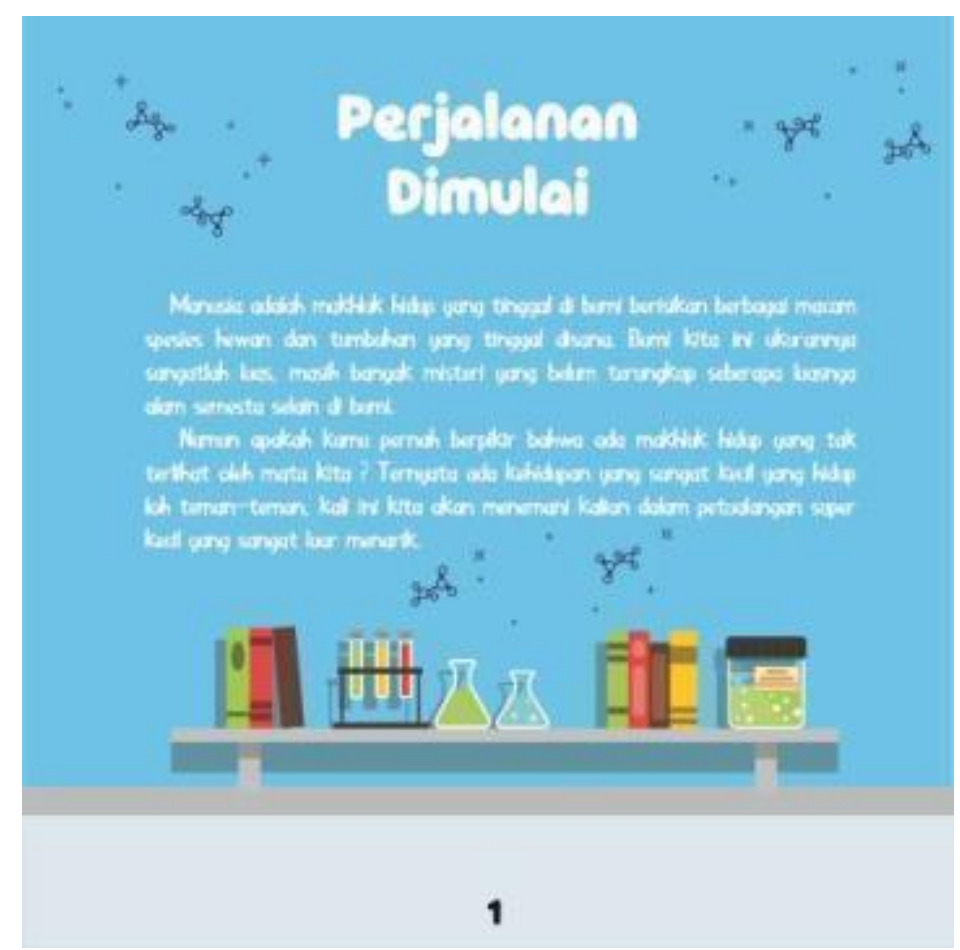

Gambar 2. Isi Pembuka dari buku cerita bergambar mikroorganisme 


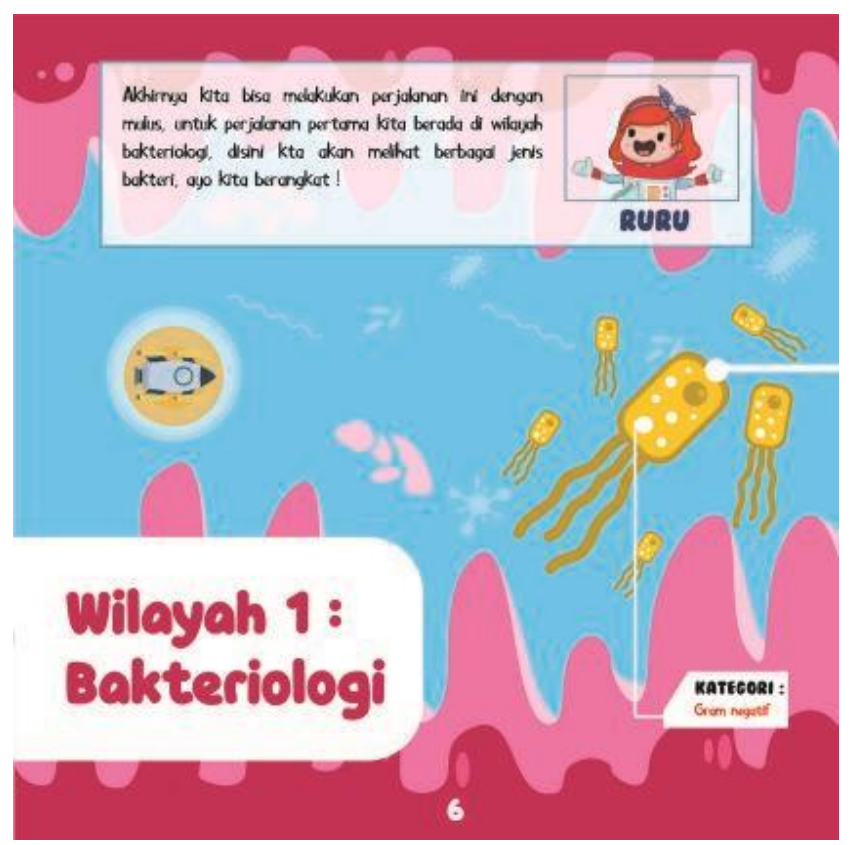

Gambar 3. Bagian isi dari buku cerita bergambar mikroorganisme

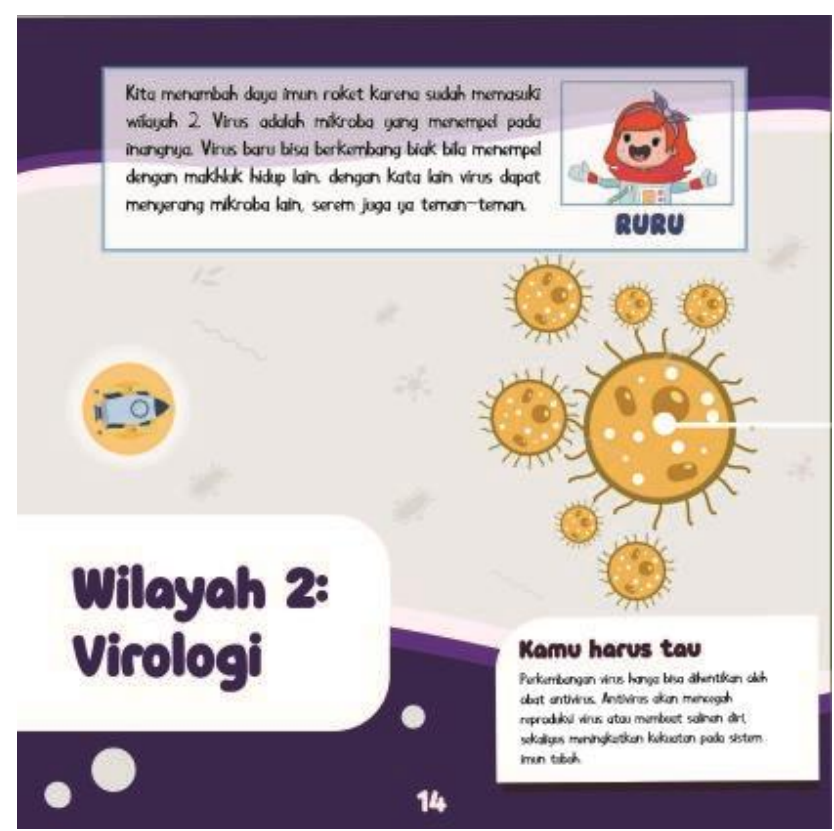

Gambar 4. Bagian isi dari buku cerita bergambar mikroorganisme 


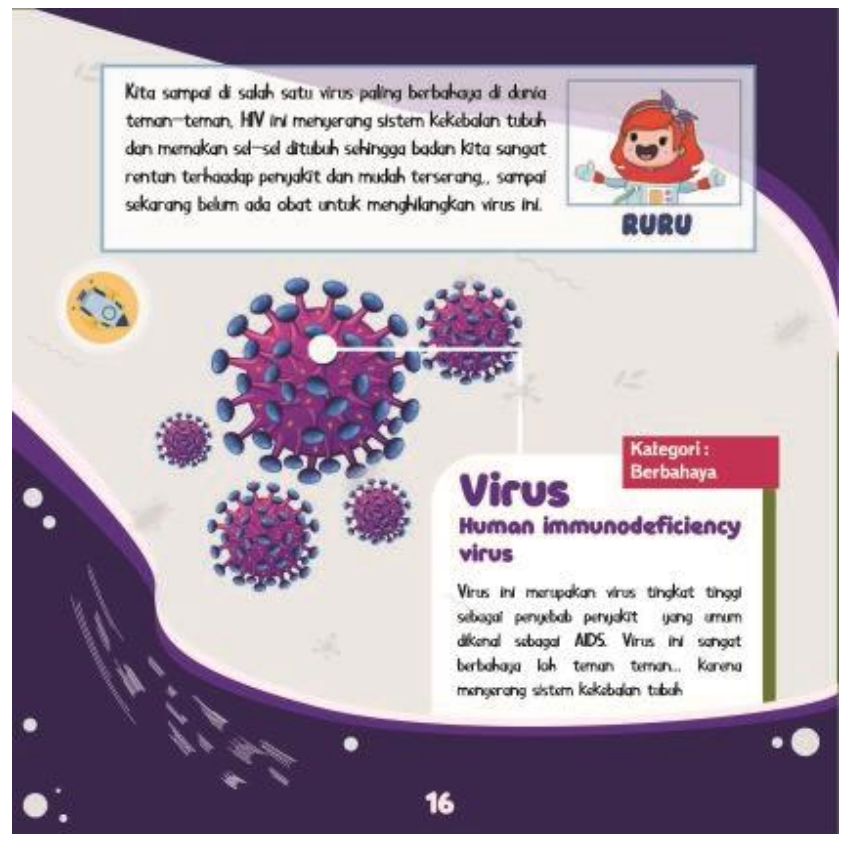

Gambar 5. Salah satu penjelasan virus di buku cerita bergambar mikroorganisme

Pada isi buku cerita bergambar ini peneliti memuat penjelasan dan informasi tentang mikroorganisme dengan sistem berjelajah dan berpetualang. Setiap jenis mikroba berganti, maka suasana tempat akan berganti pula. Peneliti juga membuat dua karakter tokoh sebagai pendamping dan pemandu, mereka akan menjelaskan serta bercerita secara naratif tentang suasana yang ada di halaman buku tersebut, terdapat fakta unik di beberapa halaman buku agar menambah pengetahuan unik tentang mikroorganisme.

\section{SIMPULAN}

Perancangan ini menghasilkan sebuah buku cerita bergambar yang terdiri dari cover dan isi buku, menggunakan konsep desain dan analisis segmentasi yang tepat dengan target utama adalah anak-anak. Menghasilkan sebuah buku cerita bergambar tentang peran mikrobiota pada tubuh yang bermanfaat dan sesuai dengan target. Konsep desain dan strategi kreatif yang diterapkan adalah menggunakan gaya ilustrasi flat design, gambar dibuat dengan warna yang cerah dan menggunakan font serif dan huruf galang yang tidak kaku untuk anak, dan pembawaan teks yang bersifat berdongeng atau naratif. Sehingga anak-anak dapat berimajinasi dan meningkatkan kreatifitas anak. Tujuan buku cerita bergambar ini memberikan isi pesan yang bersifat mengajak (persuasif), mengedukasi (edukatif) dan memberikan informasi (informatif). Perancangan buku cerita bergambar ini diharapkan dapat meningkatkan ilmu pengetahuan mengenai mikrobiologi terutama untuk anak, salah satunya adalah peran mikrobiota pada tubuh. Pengetahuan mengenai manfaat mikrobiologi dapat meningkatkan kesadaran untuk memperhatikan kesehatan dan kebersihan serta pola makan yang sehat terutama sejak kecil.

\section{DAFTAR PUSTAKA}

ChunFeng, W. (2018). Interaction between gut microbiota and the immune system. Journal of Jilin Agricultural University, 40(4), 475-479.

Emadwiandr. (2013). 済無No Title No Title. Journal of Chemical Information and Modeling, 53(9), 1689-1699.

Emosda, E. (2017). Pengaruh Penggunaan buku cerita bergambar terhadap motivasi belajar pada 
siswa sekolah dasar. Jurnal Gentala Pendidikan Dasar, 2(2), 256-274.

Halim, D., \& Munthe, A. P. (2019). Dampak Pengembangan buku cerita bergambar untuk anak usia dini. Scholaria: Jurnal Pendidikan Dan Kebudayaan, 9(3), 203-216.

Hasmiati, H., \& Jamilah, J. (2016). Hubungan antara pengetahuan mikrobiologi dengan sikap higienis Mahasiswa Pendidikan Biologi angkatan 2013 Fakultas Tarbiyah Dan Keguruan UIN Alauddin Makassar. Jurnal Biotek, 4(2), 231-243.

Kotler, P., \& Amstrong, G. (2004). Dasar-dasar pemasaran edisi kesembilan. Jilid 1. Jakarta: PT Indeks Kelompok Gramedia

Kurniati, A. M. (2016). Mikrobiota saluran cerna: Tinjauan dari aspek pemilihan asupan makanan - The gut microbiota : A Review of Diet Preferences. JK Unila, 1(2), 380-384.

Mahardika, A. D. L., Dinata, R. D. S., \& Hanindharputri, M. A. (2020). Perancangan buku cerita bergambar pengenalan tata surya kepada anak-anak di Denpasar. Jurnal Selaras Rupa, 1(1), 27-37.

Moleong, L. J. (2007). Metodologi penelitian kualitatif. Bandung: Penerbit PT Remaja Rosdakarya Offset.

Pratiwi. (2009). Panduan Penulisan skripsi, Yogyakarta: Tugu Publisher.

Rahma, N. M. (2015). Strategi peningkatan minat baca anak (Studi Pada ruang baca anak perpustakaan umum dan arsip daerah Kota Malang). Jurnal Administrasi Publik Mahasiswa Universitas Brawijaya, 3(5), 763-769.

Sanyoto, S. E. (2006). Metode perancangan komunikasi visual periklanan. Yogyakarta: Dimensi Press.

Widiayaningsih, E. N. (2011). Peran probiotik untuk kesehatan. Jurnal Kesehatan, 4(1), 14-20.

Sudarmono, P. P. (2016). Mikrobioma: Pemahaman baru tentang peran mikroorganisme dalam kehidupan manusia. EJournal Kedokteran Indonesia, 4(2).

Supriyono, R. (2010) Desain komunikasi visual: Teori dan aplikasi. Yogyakarta: Andi Offset.

Suryawan, A. (2018). Komposisi mikrobiota dan perkembangan kognitif, perilaku dan karakter anak. Maternal, Infant and Young Children Nutrition \& Health, 225-234.

Susmiati, S. (2019). Peran mikrobiota usus dalam perkembangan obesitas. Majalah Kedokteran Andalas, 42(1), 41.

Wulandari, I. (2017). Peningkatan minat baca melalui metode dongeng pada anak-anak anggota Sanggar Ruang Aksara Gayamharjo Kabupaten Sleman Yogyakarta. Jurnal Bakti Saintek: Jurnal Pengabdian Masyarakat Bidang Sains Dan Teknologi, 1(2), 73. 